\title{
PROGRAM OF THE FIFTY-THIRD ANNUAL MEETING OF THE AMERICAN SOCIETY FOR CLINICAL INVESTIGATION, INC., TO BE HELD IN ATLANTIC CITY, NEW JERSEY, MAY 1, 1961
}

1. On the Site of Viral Interference. Monto Ho, Pittsburgh, $\mathrm{Pa}$.

2. The Relative Abundance of Viral Receptors: An Explanation of the Differential Susceptibility of Suckling and Adult Mice to Coxsackie $B_{1}$ Infection. Calvin M. Kunin and Norma E. Halmagyi, Charlottesville, Ya.

3. Pyrimidine Biosynthesis in Man: Suppression In Vizo by Anti-neoplastic Agents. Mitchell Rabkin, Elizabeth Frederick, Myron Lotz and Lloyd H. Sмith, Jr., Boston, Mass.

4. Leukemic Cell Proliferation as Determined by In Vitro Deoxyribonucleic Acid (DNA) Synthesis. Charles G. Craddock and George S. Nakai, los Angeles, Calif.

5. Abnormalities of Erythrocyte and Plasma Lipids in Acanthocytosis. Peter Ways, Claude F. Reed and Donald J. Hanahan, Seattle, Wash. and Rochester, N. Y.

6. Active Transport of Iron In Vitro by Duodenal Segments and the "Mucosal Block." James G. Manis and David Schachter, New York, N. Y.

7. Response to Repeated Platelet Transfusions from the Same Donor. Emil J. Freireich, Allan Kliman, Lawrence A. Gaydos, and Leslie R. Schroeder, Bethesda, Md.

8. Bile Acid Fever and Inflammation in Man. RoBert H. Palmer, Paul B. Glickman and Attallah KaPPAs, Chicago, Ill.

9. Myocardial Blood Flow as Indicated by the Disappearance of $\mathrm{NaI}^{131}$ from the Heart Muscle. William Hollander, Irving M. Madoff and Aram V. ChoBANIAN. Boston, Mass.

10. Genetic Control of the Ability of Human Blood to Neutralize Angiotensin and Its Relationship to Essential Hypertension. J. Edwin Wood, Augusta, Ga.

11. The Influence of Arterial Pressure on the Antihypertensive Action of a Normal Kidney, a Biological Servomechanism. Louis Tobian, Beverly WinN and Jeanette Janecek, Minneapolis, Minn.

12. Relationship of Bacteriuria to Hypertension: An Epidemiological Study. Edward H. Kass, William E. Miall and Kenneth L. Stuart, Boston, Mass., Penarth, Wales, and Jamaica, W.I.

13. The Alveolar Diffusing Volume and the Water Space of the Pericapillary Tissues of the Lungs as Measured by Multiple Indicator Dilution Curves. LLOYD Ramsey, W. Puckett, A. Jose and W. Lacy, Nashville, Tenn.
14. Dominant Role of Pulmonary Vascular Engorgement as a Determinant of Dyspnea. H. Page MaUck, JR. and William Shapiro, Richmond, Va.

15. The Determination of Intracellular $\mathrm{pH}$ in Normal Human Subjects. Eugene D. RoBin, Philip A. Bromberg and Robert J. Wilson, Pittsburgh, Pa.

16. Evidence for a Renal Tubular Amino Acid Transport System Common to Glycine, L-Proline and Hydroxyl-proline. Charles R. Scriver, Irwin A. Schafer and Mary L. Efron, Montreal, Canada and Boston, Mass.

17. The Effect of Blood Glucose on Circulating Bound and Free Insulin. Harry N. Antoniades, Kare Gundersen and Hugh Pyle, Boston, Mass.

18. Relationship of Sulfhydryl Inhibitors and Reductive Conditions to the Action of Insulin on Adipose Tissue. W. S. Lynn, Jr., Eugenia Earnhardt and Rose Brown, Durham, N. C.

19. Effects of $\mathrm{PCO}_{2}$ and $\mathrm{pH}$ on the Plasma-Binding, Turnover, and Tissue Uptake of Thyroid Hormones. Milton W. Hamolsky and Myron Stein, Boston, Mass.

20. Alterations in Steroid Hormone Secretion Produced by Inhibition of Cholesterol Biosynthesis. JAMES C. Melby, Marlyn St. Cyr and S. L. Dale, Little Rock, Ark.

21. Mechanism of the Anabolic Effect of Testosterone. J. D. Wilson, Dallas, Tex.

22. Antidiuretic Hormone-like Effects of Adenosine-3', $5^{\prime}$-phosphate (Cyclic AMP) and Theophylline in the Toad Bladder. JaCk OrlofF and Joseph HaNdLeR, Bethesda, Md.

23. Human Serum Growth Hormone: Measurements of Concentration and Turnover with a Radioimmunoassay. Robert D. Utiger, Mary L. Parker and William H. Daughaday, St. Louis, Mo.

24. The Mechanism of Aldosterone Stimulation Following Hemorrhage in the Hypophysectomized Dog. Patrick J. Mulrow and William F. Ganong, New Haven, Conn. and San Francisco, Calif.

25. Biochemical Detection and Histological Study of Muscular Dystrophy in the Preclinical Stage. CARL M. Pearson, Sudhir R. Chowdhury and William M. Fowler. Los Angeles, Calif.

26. The Effects of Guanethidine on Triiodothyronineinduced Hyperthyroidism in Man. Thomas $\mathrm{E}$. Gaffney and Eugene Braunwald, Bethesda, Md. 


\section{LISTING OF EXHIBITS AT FIFTY-THIRD ANNUAL MEETING OF THE AMERICAN SOCIETY FOR CLINICAL INVESTIGATION, INC, 1961}

\section{TECHNICAL EXHIBITS}

Abbott Laboratories

Advanced Instruments, Inc.*

Beckman Instruments, Inc., Spinco Division *

Blakiston Division, McGraw-Hill Book Co., Inc.*

Warren E. Collins, Inc.

Coulter Electronics, Inc.

Dynamics Corporation of America

Electronics for Medicine, Inc.

J. H. Emerson Co.

F \& M Scientific Corporation

Gilford Instrument Laboratories, Inc.*

Grune \& Stratton, Inc.*

Paul B. Hoeber, Inc.

Instrumentation Associates, Inc.*

INSTRUMENTATION LABORATORY, INC.

LABLINE, INC.

LEA \& FEBIGER

E. LeItZ, InC.*

J. B. Lippincott Company

Little, Brown and Company

The Macmillan Company

The C. V. Mosby Company

Nuclear-Chicago Corporation *

Nuclear Industries, Inc.

Packard Instrument Company, Inc.*

Phoenix Precision Instrument Co., Inc.*

Picker X-Ray Corporation *

Sage Instruments, Inc.

Sanborn Company *

W. B. Saunders Company*

Schwarzer Co.

Servonuclear Corp.

IVAN Sorvall, Inc.*

E. R. Squibb \& Sons

Vanguard Instrument Co.

The Virtis Co., Inc.

The Waters Corporation*

The Williams \& Wilkins Co.

The Year Book Publishers, Inc.*

The Coca-Cola Company *

will serve in the exhibit area

* See advertisement in this issue.
\#53

\#8

\#42

\#31

\#25

\#1

\#51

\#36 \& \#37

\#27

\#44 \& \#45

\#38

\#23

\#46

\#4 \& \#5

\#22

\#9

\#10

\#29

\#26

\#2

\#19

\#43

\#6

\#15

\#28

\#7

\#20 \& \#21

\#47

\#16 \& \#17

\#40 \& \#41

\#34

\#39

\#24

\#33

\#50

\#35

\#3

\#52

\#30 